\title{
BACK TO BASICS: EXPERIENCING A DESTINATION THROUGH GASTRONOMY - THE CASE OF MADEIRA ISLAND
}

\author{
Soraia Garcês \\ Margarida Pocinho \\ Saúl Neves de Jesus
}

https://doi.org//10.20867/tosee.06.20

\begin{abstract}
Purpose - This study aims to explore gastronomy tourists' wellbeing in Madeira Island, Portugal, particularly those who acknowledged this activity as the experience they most enjoyed.

Methodology - Data was retrieved in 2019, and it is part of the "Wellbeing Tourists Project" developed in Madeira Island. From a preliminary sample of 475 tourists, 52 considered gastronomy their most enjoyed experience, composing this subset of participants the sample for the current study. Data collection occurred in-person (before the pandemic) and online. Tourists filled the Tourism Wellbeing Scale, which evaluates tourism experiences through positive Psychology variables [wellbeing (positive emotions, engagement, relationships, meaning, and accomplishment), creativity, optimism, and spirituality].

Findings - Tourists from England/UK, Czech Republic and Portugal (mainland) considered gastronomy their top choice. Findings showed that a gastronomy tourist in Madeira is someone who first looks to have fun, acknowledges the experience as unique/original, and enjoys engaging with the local community. Logistic regression showed that the estimated odds ratio favoured an increase of nearly 53\% for the Gastronomy experience every one unit increase of the Meaning variable.

Contribution - Madeira has a unique cuisine with unique flavours, which can be an essential attraction factor for this destination, but it is considered a complementary product. This study highlights that gastronomy should be considered a potential to promote the Island tourism and that it can also be an essential factor to promote wellbeing and Madeira food heritage.

Keywords: Gastronomy; Madeira Island; Wellbeing; Memorable Experiences.
\end{abstract}

\section{INTRODUCTION}

Gastronomy can be an intangible heritage related to a destination's own identity (Cunha 2018 , 95). Culinary experiences can be key components for a destination brand, and as Iordanova $(2015,35)$ highlighted, the destination image is a crucial strategy for marketing to empower its position and attract new potential tourists.

For Moulin $(2000,19)$, gastronomy is not seen as an asset in tourism. Almost 20 years later, the World Tourism Organization and Basque Culinary Center $(2019,8)$ stated that gastronomy was always an essential part of tourism, though, just recently, its interest has been growing and leading to new forms of tourism. Okumus $(2020,38)$ similarly stated that this tourism niche is increasingly growing. Garibaldi and Pozzi $(2018,230)$ findings suggest that gastronomy experiences boost tourists' interest, and at the same time, they can enhance product visibility and collaboration with local stakeholders. Kuznik and 
ToSEE - Tourism in Southern and Eastern Europe, Vol. 6, pp. 303-314, 2021.

S. Garcês, M. Pocinho, S.N. Jesus: BACK TO BASICS: EXPERIENCING A DESTINATION ...

Rangus $(2020,43)$, in a study developed in Slovenia about food heritage in tourism, highlighted the importance of developing local supply chains and collaboration between tourism stakeholders, products quality, and branding. While challenges exist, the World Tourism Organization and Basque Culinary Center $(2019,8)$ asserted that this tourism segment expands throughout different sectors and stakeholders, from food producers to accommodations, to the sale of products and much more. Thus, today this form of tourism is more than simply eating; but it is a way of learning and enjoying culture.

Coughlan and Saayman $(2018,235)$ found key topics regarding gastronomy preferences in tourism "social influence, culture and religion, environmental sensitivity, exploration and the culinary experience". The interaction between gastronomy tourism and local culture is also highlighted in Okumus $(2020,38)$ research which highpoints the importance of authentic and unique gastronomy experiences, and having culinary as a marketing tool. Cunha $(2018,95,97)$ also asserted that gastronomy ought to be regarded as a cultural experience of a destination and Simeon, Buonincontri, Cinquegrani and Martone $(2017,220)$ observed that "wonder, authenticity, relaxation, discovery and knowledge", were five crucial aspects of tourists' experiences regarding cultural attractions; thus, these can be understood as crucial aspects in gastronomy tourism.

Suhartanto, Dean, Sosianika, and Suhaeni (2018, 133) observed that uniqueness, authenticity, and taste/value were essential characteristics of food souvenirs for tourists' satisfaction, revealing the importance of developing products that represent the destination. Frleta $(2018,258)$ highlighted that a destination success and competitiveness is highly dependent of tourists' satisfaction. Hence, the authenticity of gastronomy experiences can be a crucial component for a destination brand. World Tourism Organization and Basque Culinary Center $(2019,33)$ also emphasised this idea, that tourists' satisfaction with gastronomy has in authenticity its most significant ally.

Virloget and Kavrečič $(2019,118)$, reflecting on the link between traditional local festivities and tourism, found that locals see two kinds of festivities. One that embraced locals' traditions and "essence" and not interested in being a publicity endeavour in tourism; and another kind, aimed to attract tourists, including selling products and presenting the public with traditions seen as a "staged authenticity". Drpić and Rudan $(2019,162)$ recognised that when authentic culture is an integral part of product offers, residents are usually more inclined to tourism development because these are part of their own identity. Nath and Saha $(2017,117)$, while discussing the idea of cultural and experiential tourism, asserted that "It is the creation of a memorable experience that matters". In this regard, the World Tourism Organization and Basque Culinary Center $(2019,32)$ empathised that the aim is to deliver a memorable and unique experience to the tourist and lead them to be personally involved and thoroughly enjoy it.

Pung and Chiappa $(2020,14,15)$, in an exploratory study regarding transformative tourism experiences, found that the interaction between locals and tourists; "facing challenges"; "experiencing the sense of the place, long-stays and post-travel reflection" are facilitators of this transformative experiences. Also, participants experienced an increase in their wellbeing in this study, aligned with the eudaimonia construct. Hence, memorable and transformative experiences have the potential to be wellbeing boosters. 
ToSEE - Tourism in Southern and Eastern Europe, Vol. 6, pp. 303-314, 2021.

S. Garcês, M. Pocinho, S.N. Jesus: BACK TO BASICS: EXPERIENCING A DESTINATION ...

For Hartwell, Fyall, Willis, Ladkin and Hemingway (2016, 1845), successful destinations apply a combination of hedonic and eudaimonic experiences. So positive Psychology or even human flourishing in tourism development can be a way to avoid a decline in products diversification and allow destinations to relocate their actions toward wellbeing and innovative approaches (Hartwell, Fyall, Willis, Ladkin and Hemingway 2016, 1846). Positive psychology applicability and potential for tourism experiences is also highlighted by Garcês, Pocinho and Jesus $(2018,109)$. If a destination wellbeing worth is acknowledged and promoted as such, and people start to realise the benefits of a healthy lifestyle, more individuals will express interest in going to places that can have a positive impact on their wellbeing (Pyke, Hartwell, Blake and Hemingway 2016, 103). Despite the potential benefits, caution is also needed, as is evident in Chin and Hampton $(2020,311)$ study where it was found in Bali that while an improvement of quality of life for locals was seen, it was on a limited scale, leading to believe that not always a successful destination translates in locals increased social wellbeing.

Nevertheless, it is true that tourism influences both wellbeing and economy; thus, bringing a health and wellbeing perspective for destinations may be a way to increase tourists visits which will eventually lead to gaining economic benefits (Pyke, Hartwell, Blake, and Hemingway 2016, 103). This can be seen in Reitsamer, and Brunner-Sperdin $(2015,55)$ research, where tourists acknowledged more psychological wellbeing when they experienced an adequate blend of both services and activities, having wellbeing a positive and significant influence return intention and positive word-of-mouth.

Memorable experiences contribute to wellbeing experiences, but not only. As Sie, Phelan and Pegg $(2018,354)$ study found, local culture and excitement, which are important characteristics of memorable experiences, also impact tourists' satisfaction with their tourism experience. Hence, as a cultural experience, gastronomy can also be a source of satisfaction with the destination and bring positive emotions. As Peršurić and Damijanić $(2016,62)$ stated, "The gastronomy of a particular tourism destination may become one of the most cherished travelling memories (...)" and, therefore, as Ramón $(2020,3)$ concluded, a "gastronomic experience and status positively affect the intentions of returning and recommending the consumption of high-end gastronomy". Likewise, Lalicic and Weismayer $(2018,80)$, in a study focused on Airbnb users, found that service quality and a social and authentic experience were significant antecedents for tourists loyalty regarding hosting services, particularly Airbnb. In Lee, Han and Ko $(2020,11)$ study, the authors explored the influence of travel on tourists' health, including psychological, physical, and social dimensions. The study found that healthy food was an important part of the experience contributing to tourists' health; however, food was also associated with experiencing a positive mood. Equally, Yu and Zhang $(2020,461)$ found that positive experiences regarding food quality improved the overall dining experience. Thus, gastronomy not only has the potential to be a memorable cultural experience but can also be an economic and wellbeing booster.

In Portugal, wellbeing is an emerging asset for the country 2027 tourism strategy combining a healthy lifestyle, health, wellbeing, mindfulness, sports, and nature activities (Turismo de Portugal 2017, 48, 49). In this same strategic document, gastronomy (and wines) is a qualifying asset. It is stated that Portugal is among one of the best fish countries, has international and recognised chefs, and its wines are one of 
ToSEE - Tourism in Southern and Eastern Europe, Vol. 6, pp. 303-314, 2021.

S. Garcês, M. Pocinho, S.N. Jesus: BACK TO BASICS: EXPERIENCING A DESTINATION ...

the best in the world. In Madeira Island an insular Portuguese territory and the case study of this paper, the tourism strategy from 2017 to 2021 has acknowledged gastronomy (including Madeira Wine) as a complementary product, a status also given to health and wellbeing products. These complementary product offers are considered important to enrich the tourists experience and their satisfaction but not "strong enough" to be main attractors to the destination (Secretaria Regional da Economia, Turismo e Cultura 2017, 102). Madeira is an international tourism destination known for its climate, nature, landscape, and culture (Carvalho, Sarmento, and Loureiro, 2017, 8). The island is in the Atlantic Ocean and has a diversity of micro-climates and a variety of rare indigenous fauna and flora (Marujo, 2013, 2, 3). Madeira has also a vast tourism history having started around the XV century with a "colonial" emphasis, transitioning to a "therapeutic" phase around the XIX century and from XX century forward is mainly known as an island of leisure and vacation (Marujo, 2013, 3, 4). Tourism is its' main economic sector and tourists have at their disposal a variety of experiences and festivities throughout the year to enjoy (Garcês, Pocinho, and Jesus, 2020a, 25). However, as mentioned above, gastronomy experiences are seen as complementary tourism offers. Yet, recently, despite this position, an exploratory research showed that gastronomy was the most enjoyable experience of tourists in Madeira and the second-best activity that promoted more wellbeing in this destination (Garcês, Pocinho and Jesus, accepted for publication). As a result, considering the relevance of gastronomy, not only as a cultural experience and economic endeavour but also as a potential for wellbeing experiences, this study aimed to further explore Madeira gastronomy tourism experience.

\section{METHODOLOGY}

\subsection{Participants}

Participants took part in the "Wellbeing Tourists' Project" developed in Madeira Island (Garcês, Pocinho and Jesus 2019, 108). Data was retrieved during 2019, pre-pandemic. From a preliminary sample of 475 tourists; 52 considered gastronomy their most enjoyed experience. Hence, this study is a subset analysis of previous research (Garcês, Pocinho and Jesus, accepted for publication) and aimed to thoroughly analyse the tourists who considered gastronomy the wellbeing experience they enjoyed the most. Ages from the participants ranged from 18 to 77 years old $(M=41.00 ; S D=17.47)$. Table 1 summarizes the participants socio-demographic characterization. 
ToSEE - Tourism in Southern and Eastern Europe, Vol. 6, pp. 303-314, 2021.

S. Garcês, M. Pocinho, S.N. Jesus: BACK TO BASICS: EXPERIENCING A DESTINATION ...

Table 1: Socio-demographic participants characterization

\begin{tabular}{llr}
\hline Socio-demographic Variables & & $\%$ \\
\hline \multirow{2}{*}{ Gender } & Women & 55.8 \\
& Men & 44.2 \\
\hline \multirow{2}{*}{ Job } & Active workers & 63.5 \\
& Non-active workers & 34.6 \\
\hline \multirow{2}{*}{ Country of Origin* } & UK/England & 21.2 \\
& Czeck Republic & 21.2 \\
& Portugal (aminland) & 13.5 \\
& Germany & 7.7 \\
& France & 5.8 \\
\hline & 7 days & 26.9 \\
Duration of stay* & 10 days & 9.6 \\
& 120 days & 9.6 \\
& 1 day & 7.7 \\
& 8 days & 7.7 \\
\hline
\end{tabular}

*Only the 5 highest percentages are highlighted.

Regarding gender the sample was composed mostly of women $(55.8 \%)$. The majority were active workers $(63.5 \%)$, and $34.6 \%$ were non-active workers. Regarding the duration of stay, it ranged from 1 day to 240 days. Most of the sample, $26.9 \%$, stayed for seven days, followed by $9.6 \%$ for ten days and $9.6 \%$ for 120 days.

\subsection{Instruments and Procedures}

The Tourism Wellbeing Scale (TWS) was used to evaluate tourists' experiences. This instrument follows a Positive Psychology perspective applied to tourism settings (Garcês, Pocinho and Jesus, 2020b, 3). It is composed of eight items/questions that evaluate: positive emotions, engagement, relationships, meaning, accomplishment, creativity, optimism, and spirituality. It also evaluates the overall wellbeing experience. Responses occur through a Likert scale from 1 (Totally Disagree) to 7 (Totally Agree). The validation study reported reliability values of 0.874 (Garcês, Pocinho and Jesus $2020 \mathrm{~b}, 7)$; for the current study, reliability was 0.826 of the overall scale.

Data collection occurred before the pandemic on the streets of Madeira capital city Funchal, after permission from the City Hall and online. Data was then inserted and analysed through SPSS regarding only the tourists who acknowledged Madeira gastronomy as their number one experience. Descriptive and inferential (t-test) analyses were performed to characterize the sample and to compare the means of groups and test hypothesis for potential gender differences. Thus, the following hypothesis was proposed considering previous research: gender has no effect in Madeira wellbeing experiences (Garcês, Pocinho and Jesus, accepted for publication). Logistic regression was also conducted as a predictive analysis to explore the possibility to predict tourists choosing gastronomy through psychological variables of wellbeing. Thus, the gastronomy experience was the dependent variable $(0=$ tourists who have not chosen gastronomy this selection was made randomly; $1=$ tourists who have chosen gastronomy as their most enjoyed experience) and the wellbeing variables (TWS) the predictors. 
ToSEE - Tourism in Southern and Eastern Europe, Vol. 6, pp. 303-314, 2021.

S. Garcês, M. Pocinho, S.N. Jesus: BACK TO BASICS: EXPERIENCING A DESTINATION ...

\subsection{Results}

A t-test analysis was performed to observe the possibility of gender differences for the different variables evaluating wellbeing (Table 2). As can be seen in Table 2, no gender differences were found, confirming the proposed hypothesis

Table 2: Gender differences

\begin{tabular}{|c|c|c|}
\hline Variable/ Item & $\mathrm{t}$ & $p$ \\
\hline $\begin{array}{l}\text { 1. I found out new ways of being that gave meaning to aspects of my } \\
\text { life. - Meaning. }\end{array}$ & -0.176 & 0.861 \\
\hline 2. I had lots of fun - Positive Emotions. & 0.112 & 0.911 \\
\hline $\begin{array}{l}\text { 3. I was able to see the positive side of the less agreeable situations } \\
\text { that occurred - Optimism }\end{array}$ & -0.244 & 0.808 \\
\hline 4. I faced this experience as a unique/original opportunity - Creativity). & -0.104 & 0.918 \\
\hline $\begin{array}{l}\text { 5. I engaged in the community activities (ex. Cultural, events, etc.) - } \\
\text { Engagement. }\end{array}$ & -0.047 & 0.963 \\
\hline 6. This experience was a dream come true - Accomplishment. & 0.991 & 0.327 \\
\hline $\begin{array}{l}\text { 7. I experienced a connection/relationship with something higher } \\
\text { than myself - Spirituality. }\end{array}$ & 0.460 & 0.648 \\
\hline $\begin{array}{l}\text { 8. I felt food in the relationship I developed with new people - } \\
\text { Relationships. }\end{array}$ & -0.018 & 0.986 \\
\hline Overall Wellbeing & 0.390 & 0.698 \\
\hline
\end{tabular}

Source: Own elaboration

Results showed that tourists from England/United Kingdom and the Czech Republic considered gastronomy as their top choices, acknowledging each country for $21.2 \%$ of the sample. In third place $(13.5 \%)$ were Portuguese from the mainland.

Following an in-depth analysis of these participants wellbeing, Table 3 presents its rankings with a descriptive statistical analysis for this subset of tourists.

Table 3: Gastronomy tourists wellbeing rankings

\begin{tabular}{lcccc}
\hline Variable/ Item & $\begin{array}{c}\text { Mean } \\
(M)\end{array}$ & $\begin{array}{c}\text { Standard } \\
\text { Deviation } \\
(S D)\end{array}$ & Skewness & Kurtosis \\
\hline $\begin{array}{l}\text { 1. I found out new ways of being that } \\
\text { gave meaning to aspects of my life }- \\
\text { Meaning }\end{array}$ & 5.62 & 1.33 & -1271 & 2.012 \\
$\begin{array}{l}\text { 2. I had lots of fun - Positive Emotions. } \\
\text { 3. I was able to see the positive side of } \\
\text { the less agreeable situations that }\end{array}$ & $\mathbf{6 . 2 3}$ & 0.76 & -0.981 & 1.232 \\
$\begin{array}{l}\text { occurred - Optimism. } \\
\text { I faced this experience as a } \\
\text { unique/original opportunity - }\end{array}$ & $\mathbf{5 . 4 4}$ & 0.94 & -0.123 & -0.867 \\
$\begin{array}{l}\text { Creativity. } \\
\text { I engaged in the community activities } \\
\text { (ex. Cultural, events, etc.) - }\end{array}$ & $\mathbf{5 . 9 4}$ & 0.87 & -0.438 & -0.486 \\
$\quad$ Engagement. & $\mathbf{5 . 7 3}$ & 1.14 & -1.757 & 4.971 \\
\hline
\end{tabular}


ToSEE - Tourism in Southern and Eastern Europe, Vol. 6, pp. 303-314, 2021.

S. Garcês, M. Pocinho, S.N. Jesus: BACK TO BASICS: EXPERIENCING A DESTINATION ...

Table 3 (continued)

\begin{tabular}{lcccc}
\hline Variable/ Item & $\begin{array}{c}\text { Mean } \\
(M)\end{array}$ & $\begin{array}{c}\text { Standard } \\
\text { Deviation } \\
(S D)\end{array}$ & Skewness & Kurtosis \\
\hline 6. $\begin{array}{l}\text { This experience was a dream come } \\
\text { true - Accomplishment. }\end{array}$ & 5.45 & 1.14 & -0.541 & 0.608 \\
$\begin{array}{l}\text { 7. experienced a } \\
\text { connection/relationship with } \\
\text { something higher than myself - }\end{array}$ & 5.29 & 1.59 & -0.924 & 0.522 \\
$\begin{array}{l}\text { Spirituality. } \\
\text { I felt good in the relationship I } \\
\text { developed with new people - }\end{array}$ & 5.69 & 1.18 & -1.002 & 0.990 \\
$\begin{array}{l}\text { Relationships. } \\
\text { Overall Wellbeing }\end{array}$ & 45.29 & 5.41 & -0.616 & 0.168 \\
\hline
\end{tabular}

Source: Own elaboration

Table 3 results suggest that Madeira's food tourists present the following wellbeing ranking: $1^{\circ}$ positive emotions; $2^{\circ}$ creativity; $3^{\circ}$ engagement $4^{\circ}$ relationships $; 5^{\circ}$ meaning; $6^{\circ}$ accomplishment; $7^{\circ}$ optimism; and $8^{\circ}$ spirituality. The three most rated variables allow to hypothesize that these gastronomy tourists' are someone who look to have fun, acknowledge the experience as unique/original and enjoy to engage with the local community.

A logistic regression analysis to investigate if there is a relationship between wellbeing and the gastronomy experience was conducted. Table 4 presents the results for this analysis.

Table 4: Logistic Regression for the gastronomy experience

\begin{tabular}{|c|c|c|c|c|c|c|}
\hline & \multirow[t]{2}{*}{ B } & \multirow[t]{2}{*}{ SE } & \multirow[t]{2}{*}{ Sig. } & \multicolumn{3}{|c|}{$95 \% \mathrm{CI}$} \\
\hline & & & & Lower & $\begin{array}{l}\text { Odds } \\
\text { Ratio }\end{array}$ & Upper \\
\hline Constant & -3.357 & 1.843 & & & 0.035 & \\
\hline $\begin{array}{l}\text { 1. I found out new ways of } \\
\text { being that gave meaning } \\
\text { to aspects of my life. - } \\
\text { Meaning. }\end{array}$ & 0.426 & 0.209 & $.042 *$ & 1.016 & 1.530 & 2.306 \\
\hline $\begin{array}{l}\text { 2. I had lots of fun - } \\
\text { Positive Emotions. }\end{array}$ & 0.187 & 0.243 & .441 & 0.749 & 1.206 & 1.943 \\
\hline $\begin{array}{l}\text { 3. I was able to see the } \\
\text { positive side of the less } \\
\text { agreeable situations that } \\
\text { occurred - Optimism. }\end{array}$ & 0.125 & 0.215 & .563 & 0.743 & 1.133 & 1.728 \\
\hline $\begin{array}{l}\text { 4. I faced this experience } \\
\text { as a unique/original } \\
\text { opportunity -Creativity. }\end{array}$ & -0.167 & 0.242 & .489 & 0.527 & 0.846 & 1.358 \\
\hline $\begin{array}{l}\text { 5. engaged in the } \\
\text { community activities } \\
\text { (ex. Cultural, events, } \\
\text { etc.) - Engagement. }\end{array}$ & 0.157 & 0.173 & .363 & 0.834 & 1.171 & 1.644 \\
\hline
\end{tabular}


ToSEE - Tourism in Southern and Eastern Europe, Vol. 6, pp. 303-314, 2021.

S. Garcês, M. Pocinho, S.N. Jesus: BACK TO BASICS: EXPERIENCING A DESTINATION ...

Table 4 (continued)

\begin{tabular}{|c|c|c|c|c|c|c|c|}
\hline & \multirow[t]{2}{*}{ B } & \multirow[t]{2}{*}{ SE } & \multirow[t]{2}{*}{ Sig. } & \multicolumn{3}{|c|}{$95 \%$ CI } \\
\hline & & & & & Lower & $\begin{array}{l}\text { Odds } \\
\text { Ratio } \\
\end{array}$ & Upper \\
\hline 6. & $\begin{array}{l}\text { This experience was a } \\
\text { dream come true - } \\
\text { Accomplishment. }\end{array}$ & -0.035 & 0.204 & .863 & 0.647 & 0.965 & 1.440 \\
\hline 7. & $\begin{array}{l}\text { I experienced a } \\
\text { connection/ } \\
\text { relationship with } \\
\text { something higher than } \\
\text { myself - Spirituality. }\end{array}$ & 0.302 & 0.204 & .139 & 0.907 & 1.352 & 2.017 \\
\hline 8. & $\begin{array}{l}\text { I felt food in the } \\
\text { relationship I } \\
\text { developed with new } \\
\text { people - Relationships. }\end{array}$ & -0.333 & 0.235 & .156 & 0.453 & 0.717 & 1.136 \\
\hline
\end{tabular}

Note. $\mathrm{R}^{2}=0.129$ (Hosmer \& Lemeshow), 0.164 (Cox \& Snell), 0.219 (Nagelkerke). Model $\chi 2(8)=19.685$, $p<.05 ; * p<.05$; Source: Own elaboration

The predictor variables were considered the eight items (positive emotions, engagement, relationships, meaning, accomplishment, creativity, optimism, and spirituality) that compose the TWS. The predictor variable, namely the item "I found out new ways of being that gave meaning to aspects of my life" (item 1) - Meaning - in the logistic regression analysis was found to contribute to the model. The unstandardized Beta weight for the constant was: $B=-3.357, S E=1.843$, Wald $=3,320, p>.05$. The unstandardized Beta weight for the predictor variable was: $B=0.426, S E=0.209$, Wald $=4.143, p<.05$. The estimated odds ratio favoured an increase of nearly $53 \%$ $[\operatorname{Exp}(B)=1.530,95 \% \mathrm{CI}(1.016,2.306)]$ for the gastronomy experience every one unit increase of the Meaning variable (item 1 of the TWS).

\section{CONCLUSION}

Throughout the last few decades, gastronomy experiences have been receiving a more standout position within the industry (Okumus 2020, 38), including its link to the destination identity and its potential to promote memorable and wellbeing experiences (World Tourism Organization and Basque Culinary Center 2019, 8, 32). This study explored this tourism segment within a particular setting, Madeira Island in Portugal. As a sub-tropical destination, Madeira has a unique cuisine with unique flavours, which can be an essential attraction factor.

The island gastronomy has influences from its climate, allowing to grow many typical native foods that represent its local gastronomy (Sousa, and Mota, 346) and thus its food authenticity. Many of these foods are differentiating elements of Madeira, for example "bolo do caco", Madeira wine, or "poncha". These and many others "make Madeira a unique and special island" (Carvalho, Sarmento, and Loureiro, 2017, 25). However, policymakers consider gastronomy a complementary product (Secretaria Regional da Economia, Turismo e Cultura 2017, 102). 
ToSEE - Tourism in Southern and Eastern Europe, Vol. 6, pp. 303-314, 2021.

S. Garcês, M. Pocinho, S.N. Jesus: BACK TO BASICS: EXPERIENCING A DESTINATION ...

This exploratory study highlights that gastronomy can be an important part of the Madeira experience. A niche of tourists addressed gastronomy as their primary choice of activity/experience in Madeira. This fact alone should at least lead to an in-depth analysis of the potential of this product within the market offers to increase its position from a complementary product to potentially a primary one. Gastronomy can be a tourism attractor (Garibaldi and Pozzi 2018, 230), bringing economic gains (Lalicic and Weismayer 2018, 80; Ramón 2020,3), but it can also be considered intangible heritage (Cunha 2018, 95), reflecting the day-to-day life of locals as authentic as possible (Carral, Río and López 2020, 21).

Results showed that beyond England/United Kingdom; Czech Republic and Portugal (mainland) put gastronomy as their number one experience. This fact is promising because policymakers put France, Netherlands, United Kingdom, Germany, and Spain as the primary consumers of Madeira gastronomy (Secretaria Regional da Economia, Turismo e Cultura 2017, 102). The Czech Republic and Portugal (mainland) may be a new market niche worth exploring for future promotion strategies. Findings also suggest that gastronomy tourists find the experience full of fun, originality, and engagement with the local community. As Peršurić and Damijanić $(2016,62)$ stated, gastronomy can be a most valuable memorable experience. Thus, aligning a sense of fun or hedonia with wellbeing concepts of eudaimonia should be taken both into account when designing experiences (Hartwell, Fyall, Willis, Ladkin and Hemingway 2016, 1846).

Results show that gastronomy tourists in Madeira want both: an experience to have a nice moment, an experience that is different and an experience that allows them to feel engaged with the local culture and its residents. Thus, gastronomy can be a way to promote the Island's history, culture, and traditions, contributing to maintaining its (food) heritage, allowing tourists to experience the Island and residents to talk about their unique culinary history. As the World Tourism Organization and Basque Culinary Center $(2019,34)$ highlighted, stories and their people bring uniqueness to the experience and telling a story with a humanistic approach is crucial for gastronomy identity.

Also, a significant result from this study is the fact that a regression model was possible to obtain, leading to conclude that those tourists who identified themselves as able to find new ways of being that give meaning to different aspects of their life - have a chance of $53 \%$ more to choose gastronomy experiences in Madeira. These results suggest why not look further to gastronomy in Madeira and promote memorable experiences through food? As Yousaf, Amin and Santos $(2018,208)$ stated, people's needs, principles, gains, and attitudes can be employed to comprehend tourism; thus, these should be acknowledged in promotion strategies.

Food experiences are not only a need anymore, but also have a deeper meaning in travel experiences being a way to also enjoy the destination culture (World Tourism Organization and Basque Culinary Center 2019, 8), as the logistic regression in this study is showing. Even without in-depth promotion, gastronomy looks like an asset to tourism experiences in Madeira. While this is an exploratory study with limitations including size sample, future ones should follow since this research showed potential for food experiences in Madeira. 
ToSEE - Tourism in Southern and Eastern Europe, Vol. 6, pp. 303-314, 2021.

S. Garcês, M. Pocinho, S.N. Jesus: BACK TO BASICS: EXPERIENCING A DESTINATION ...

In practice these results should lead to a rethinking of current marketing strategies (and maybe develop new ones) where an emphasis in gastronomy experiences in Madeira and its authenticity should be highlighted. This dissemination should also be aimed to different target countries such as Czech Republic, since the study showed that gastronomy is of interest for tourists from countries not initial considered by regional tourism institutions. This research can also be a starting point to develop customized experiences based on tourists' psychological characteristics, and thus innovating the product offers of this destination.

In conclusion, gastronomy is a multifaceted endeavour with multiple stakeholders, but it can be a resource to promote destinations' authenticity and well-being, a must for today's tourism experiences, while still leading to economic gains.

\section{ACKNOWLEDGEMENTS}

The initial research for this paper was financially supported by ARDITI - Regional Agency for Development of Research, Technology and Innovation of Madeira, Project M1420-09-5369-FSE000001, Madeira 14-20 Program, through a post-doctoral research grant of the first author.

This paper is financed by National Funds provided by FCT- Foundation for Science and Technology through project UIDB/04020/2020.

\section{REFERENCES}

Carral, E., Río, M. and López, Z. (2020), "Gastronomy and Tourism: Socioeconomic and Territorial Implications in Santiago de Compostela-Galiza (NW Spain”, Int. J. Environ. Res. Public Health, Vol. 17, pp- 61-73. doi:10.3390/ijerph1717617

Carvalho, T. F. F., Sarmento, E. M., and Loureiro, S. M. C. (2017), "Insights about destination brand: Madeira case study", Tourism and Hospitality International Journal, Vol. 9, No. 1, pp. 12-33.

Chin, W. and Hampton M. (2020), "The relationship between destination competitiveness and residents' quality of life: lessons from Bali”, Tourism and Hospitality Management, Vol. 26, No. 2, pp. 311-336.

Coughlan, L.M. and Saayman, M. (2018), "The relationship between the culinary preference and culinary satisfaction", Tourism and Hospitality Management, Vo. 24, No. 2, pp. 235-255.

Drpić, D. and Rudan, E. (2019), "Event Competitiveness in Heritage Tourism in Rural Croatia", Academica Turistica, Vol. 12, No. 2, pp. 161-172.

Frleta, D. (2018), "Shifts in tourists' attitudes towards the destination offering", Tourism and Hospitality Management, Vol. 24, No. 2, pp. 257-270.

Garcês, S., Pocinho, M. and Jesus, S. (2020a), "The Best Tourism Island Destination in the World and Meaningful Experiences: A Systematic Literature Review", Revista Portuguesa de Estudos Regionais, Vol. 1, No. 53, pp. 23-24.

Garcês, S., Pocinho, M. and Jesus, S. (2020b), "Psychometric analysis of the Tourism Wellbeing Scale (TWS): a multidisciplinary approach", Anais da Academia Brasileira de Ciências, Vol. 92, No. 1, e20190232. doi: https://doi.org/10.1590/0001-3765202020190232

Garcês, S., Pocinho, M. and Jesus, S. (accepted for publication), "Madeira island tourists psychological profile and wellbeing", in Scott, N. (Ed), Managing Destinations: From Theories to Practices, Emerald Publishing, United Kingdom.

Garcês, S., Pocinho, M. and Jesus, S. (2018), "Review of Optimism, Creativity, and Spirituality", Tourism and Hospitality Management, Vol. 24, No. 1, pp. 107-117. doi: https://doi.org/10.1590/00013765202020190232

Garcês, S., Pocinho, M. and Jesus, S. (2019), "Psychological Wellbeing as a Creative Resource for Businesses in the Tourism Industry: A Multidisciplinary View", in Teixeira, S.J. and Ferreira, J.M. (Eds), Multilevel Approach to Competitiveness in the Global Tourism Industry, IGI Global, USA, pp. 98-119. 
ToSEE - Tourism in Southern and Eastern Europe, Vol. 6, pp. 303-314, 2021.

S. Garcês, M. Pocinho, S.N. Jesus: BACK TO BASICS: EXPERIENCING A DESTINATION

Garibaldi, R. and Pozzi, A. (2018), "Creating tourism experiences combining food and culture: an analysis among Italian producers", Tourist Review, Vol. 73, No. 2, pp. 230-241.

Hartwell, H. Fyall, A., Willis, C., Page, S., Ladkin, A. and Hemingway (2016), "Progress in tourism and destination wellbeing research", Current Issues in Tourism, Vol. 21, pp. 1830-1892. https://doi.org/10.1080/13683500.2016.1223609

Iordanova, E. (2015), "Unravelling the complexity of destination image formation: A conceptual framework", European Journal of Tourism Research, Vol. 11, pp. 35-56.

Kužnik, L. and Rangus, M. (2020),. “"There Is No Lunch without Potatoes': Culinary Heritage of the Posavje Region in Tourism Supply”, in Peštek, A., Kukanja, M. and Renko, S. (Eds), Gastronomy for Tourism Development, Emerald Publishing, United Kingdom, pp. 43-65.

Lalicic, L. and Weismayer, C. (2018), “A model of tourists' loyalty: the case of Airbnb”, Journal of Hospitality and Tourism Technology, Vol. 9, No. 1, pp. 80-93. https://doi.org/10.1108/JHTT-02-2017-0020

Lee, T., Han, J. and Ko, T. (2020), "Health-Oriented Tourists and Sustainable Domestic Tourism", Sustainability, Vol. 12, 4988. doi:10.3390/su12124988

Marujo, N. (2013), "O desenvolvimento do turismo na Ilha da Madeira", Turydes - Revista de Investigación en Turismo y Desarrollo Local, Vol. 6, No. 15, pp. 1-16.

Moulin, C. (2000), "Gastronomy and tourism: Must every tourist wish be our command?", Tourist Review, Vol. 55, No. 1, pp. 19-24. https://doi.org/10.1108/eb058326

Nath, A. and Saha, P. (2017), "A Theoretical Positioning of Self and Social Identities as Antecedents in Cultural-Experiential Tourism", Academica Turistica, Vol. 12, No. 2, pp. 115-128.

Okumus, B. (2020), "Food tourism research: a perspective article", Tourism Review, Vol. 76, No. 1, pp. 3842. https://doi.org/10.1108/TR-11-2019-0450

Peršurić, A. and Damijanić, A. (2016), “Tourists' Attitudes towards Ecologically-Produced Food”, Academica Turistica, Vol. 9, No. 1, pp.61-71.

Pung, J. and Chiappa, G. (2020), "An exploratory and qualitative study on the meaning of transformative tourism and its facilitators and inhibitors", European Journal of Tourism Research, Vol. 24, 2404.

Pyke, S., Hartwell, H., Blake, A. and Hemingway, A. (2016), "Exploring wellbeing as a tourism product resource", Tourism Management, Vol. 55, pp. 94-105. https://doi.org/10.1016/j.tourman.2016.02.004

Ramón, N. (2020), "Relational dynamics of high-level gastronomy in tourism. Doctoral Dissertation Summary", European Journal of Tourism Research, Vol. 24, 2413.

Secretaria Regional da Economia, Turismo e Cultura 2017, Estratégia para o Turismo da Madeira 2017-2021, viewed 30 april, 2021 https://www.apmadeira.pt/media/1731/estrategia-para-o-turismo-damadeira.pdf

Sie, L., Phelan, K. and Pegg, S. (2018), "The interrelationships between self-determined motivations, memorable experiences and overall satisfaction: A case of older Australian educational tourists", Journal of Hospitality and Tourism Technology, Vol. 9, No. 3, pp. 354-379. https://doi.org/10.1108/JHTT-092017-0098

Simeon, M., Buonincontri, P., Cinquegrani, F. and Martone, A. (2017), "Exploring tourists' cultural experiences in Naples through online reviews", Journal of Hospitality and Tourism Technology, Vol. 8, No. 2, pp. 220-238. https://doi.org/10.1108/JHTT-10-2016-0067

Sousa, B., and Mota, L. (2019), "Local products and gastronomy valuation for tourism and food sustainability in the Autonomous Region of Madeira", Proceedings Book - XI International Tourism Congres. (ITC'19), Funchal, 5-7 November.

Suhartanto, D., Dean, D., Sosianika, A. and Suhaeni, T. (2018), "Food souvenirs and their influence on touris satisfaction and behavioural intentions", European Journal of Tourism Research, Vol. 18, pp. 133 -145.

Turismo de Portugal 2017, Estratégia Turismo 2017, viewed 30 april, 2021 https://www.turismodeportugal.pt/SiteCollectionDocuments/estrategia/estrategia-turismo-2027.pdf

Virloget, K. and Kavrečič, P. (2019), "Traditional Festivities in North Istria in Terms of Authenticity and (Dis)Continuity", Academica Turistica, Vol. 12, No. 2, pp. 109-120.

World Tourism Organization and Basque Culinary Center (2019), "Guidelines for the Development of Gastronomy Tourism", UNWTO, Madrid.

Yousaf, A. Amin, I. and Santos, J. (2018), “Tourists' motivations to travel: a theoretical perspective on the existing literature", Tourism and Hospitality Management, Vol. 24, No. 1, pp. 197-211.

Yu, C. and Zhang, X. (2020), "The embedded feelings in local gastronomy: a sentiment analysis of online reviews", Journal of Hospitality and Tourism Technology, Vol. 11, No. 3, pp. 461-478. https://doi.org/10.1108/JHTT-02-2019-0028 
ToSEE - Tourism in Southern and Eastern Europe, Vol. 6, pp. 303-314, 2021.

S. Garcês, M. Pocinho, S.N. Jesus: BACK TO BASICS: EXPERIENCING A DESTINATION ...

Soraia Garcês, $\mathrm{PhD}$, Assistant Professor

University of Madeira/CIERL and Research Center for Tourism, Sustainability and Well-being Universidade do Algarve

Campus Universitário da Penteada, Funchal, Portugal

(+351) 931649373

soraia@staff.uma.pt

Margarida Pocinho, PhD, Professor with Habilitation

University of Madeira/CIERL and Research Center for Tourism, Sustainability and Well-being Universidade do Algarve

Campus Universitário da Penteada, Funchal, Portugal

(+351) 966511792

mpocinho@staff.uma.pt

Saúl Neves de Jesus, PhD, Vice-Rector

Research Center for Tourism, Sustainability and Well-being - Universidade do Algarve Campus

Universitário de Gambelas, Faro, Portugal

(+351) 965053506

sjneves@ualg.pt 